\title{
SEASONAL VARIATIONS IN FAUNAL DISTRIBUTION AND ACTIVITY ACROSS THE CONTINENTAL SLOPE OF THE GOBAN SPUR AREA (NE ATLANTIC)
}

\author{
ELS FLACH and CARLO HEIP \\ Centre for Estuarine and Coastal Ecology, Netherlands Institute of Ecology (NIOO-CEMO), Vierstraat 28, NL-4401 EA \\ Yerseke, The Netherlands
}

\begin{abstract}
Density, biomass and community structure of macrofauna were estimated together with several sediment characteristics at seven stations ranging from $208 \mathrm{~m}$ to $4460 \mathrm{~m}$ water depth along the OMEX transect in the Goban Spur area (NE Atlantic) during three seasons (October 1993, May 1994, and August 1995). Median grain size decreased with increasing water depth and showed no differences between the seasons. The percentages of organic carbon and total nitrogen were highest at mid-slope depths $(\sim 1000$ to $1500 \mathrm{~m})$, and were significantly higher in August at the upper part of the slope to a depth of $\sim 1500 \mathrm{~m}$. The $\mathrm{C}: \mathrm{N}$ ratio in the surface layer amounted to $\sim 7$ to 8 in May, $\sim 10$ to 12 in August and $\sim 14$ to 17 in October at all stations (except the deepest at $4460 \mathrm{~m}$, where it was $\sim 11$ in May and August), indicating arrival of fresh phytodetritus in May, and therefore seasonality in food input to the benthos. Densities of macrofauna decreased exponentially with increasing water depth. Significantly higher densities of macrofauna were found in May at the upper part of the slope to a depth of $\sim 1500 \mathrm{~m}$. These differences were mainly due to high numbers of postlarvae of echinoids at the shallowest station and ophiuroids at the deeper stations. Biomass values also decreased with increasing water depth, but biomass was relatively high at the $\sim 1000 \mathrm{~m}$ station and low at $\sim 1500 \mathrm{~m}$, due to relatively high and low mean weights of the individual macrofaunal specimens. No significant differences in biomass were found between the seasons. Respiration was high $\left(15\right.$ to $\left.20 \mathrm{mgC} \cdot \mathrm{m}^{-2} \cdot \mathrm{d}^{-1}\right)$ in May at the upper part of the slope to a depth of $\sim 1000 \mathrm{~m}$ and low $\left(1-3 \mathrm{mg} \mathrm{C} \cdot \mathrm{m}^{-2} \cdot \mathrm{d}^{-1}\right)$ at the deeper part. At the shallowest stations to a depth of $\sim 1000 \mathrm{~m}$ respiration was highest in May, at the mid-slope stations $(\sim 1400-2200 \mathrm{~m})$ it was highest in August, whereas the deepest stations $(\sim 3600$ to $4500 \mathrm{~m})$ did not show any differences in respiration rates. In conclusion: seasonal variation in organic input is reflected in density, community structure and activity of the macrofauna along the continental slope in the NE Atlantic.
\end{abstract}

Keywords: Seasonal variation, macrofauna, continental slope, NE Atlantic, C:N ratio

\section{INTRODUCTION}

The general aim of the Ocean Margin EXchange (OMEX) programme of the EU is to study the physical, chemical and biological processes at the ocean margins -the shelf break and the continental slopethat determine the transport of material from the shelf to the deep sea. The aim of the subproject Benthic Biology within OMEX is to evaluate the role of biological process in the benthic boundary layer and in the sediments in the cycling of particulate organic material. Structural characteristics of benthic communities such as density, biomass, vertical distribution and community structure can give important indirect information on the quantity and quality of organic material arriving at the sea floor and the burial of organic material in the sediments.

Over the last fifteen years, evidence has accumulated that the deep-sea floor is not a stable environment, but shows seasonal variation. Billett et al. (1983) reported seasonal pulses of phytodetrital material to bathyal and abyssal depths in the Porcupine Seabight in the NE Atlantic. This material appears to originate directly from the surface primary production and to sink rapidly to the deep-sea floor (Billett et al., 1983). Once on the sea bed, the detrital 
macrofauna density
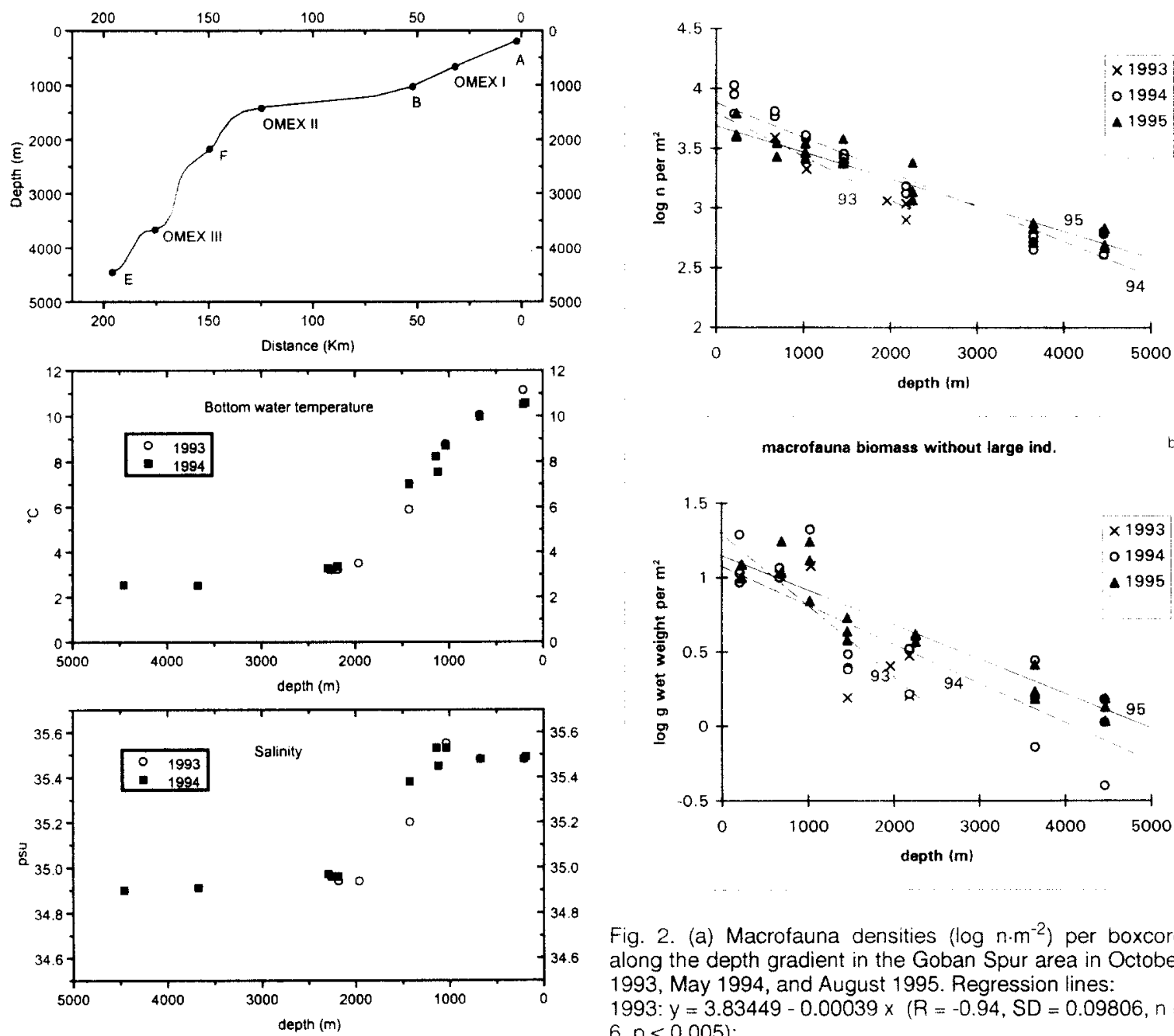

Fig. 2. (a) Macrofauna densities $\left(\log n \cdot m^{-2}\right)$ per boxcore along the depth gradient in the Goban Spur area in October 1993, May 1994, and August 1995. Regression lines:

1993: $y=3.83449-0.00039 \times(R=-0.94, S D=0.09806, n=$ $6, p<0.005)$

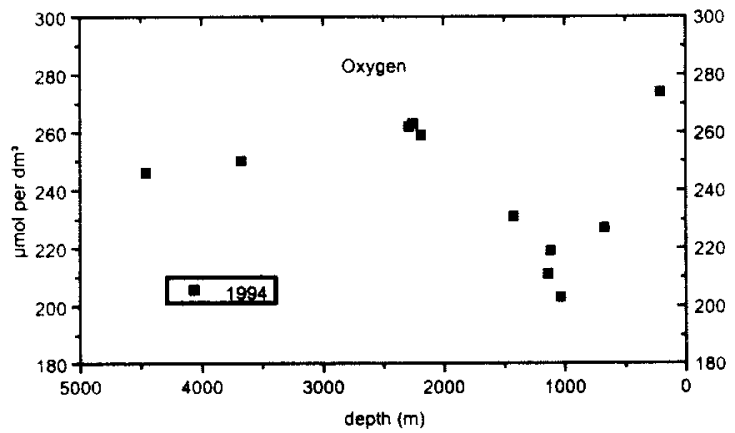

1994: $y=3.91751-0.0003 \times(R=-0.97, S D=0.12064, n=$ $18, p<0.001$ )

1995: $y=3.71399-0.00023 \times(R=0.96, n=20, p<0.001)$. (b) Macrofauna biomass with exclusion of some extremely large individuals ( $\log \mathrm{g}$ wet weight $\cdot \mathrm{m}^{-2}$ ). Regression lines: 1993: $y=1.33086-0.00049 \times(R=-0.78, n=6, p=0.064)$; 1994: $y=1.15863-0.00028 \times(R=-0.85, n=18, p<0.001)$; 1995: $y=1.17478-0.00024 \times(R=-0.93, n=20, p<0.001)$.

Fig. 1. Depth-profile and sampling stations of the OMEX transect. Bottom water characteristics, temperature $\left({ }^{\circ} \mathrm{C}\right)$, salinity (PSU) and oxygen $\left(\cdot \mathrm{dm}^{-3}\right)$ along the OMEX transect. Data copied (with permission) from the cruise reports (Helder, 1993; Van Weering, 1994).

material is moved over the sediment surface by bottom currents. When currents exceed about $7 \mathrm{~cm} \cdot \mathrm{s}^{-1}$ (at $1 \mathrm{~m}$ above the bottom), the material is resuspended (Lampitt, 1985). Lampitt (1985) speculates that because resuspension of the detritus will make the material more readily available to suspension feeders, quite subtle changes in the near-bottom current regime may have substantial effects on the struc- 
TABLE 1

Sampling stations for meio- and macrofauna along the OMEX transect. $\varnothing=$ diameter of boxcore. $O=$ total area sampled.

\begin{tabular}{|c|c|c|c|c|c|c|c|}
\hline \multirow[t]{2}{*}{ station } & \multirow{2}{*}{$\begin{array}{c}\text { sampling } \\
\text { date }\end{array}$} & \multirow[t]{2}{*}{ position $N$} & \multirow[t]{2}{*}{ position W } & \multirow[t]{2}{*}{ depth $(m)$} & \multicolumn{2}{|c|}{ macrofauna } & \multirow[b]{2}{*}{$O(\mathrm{~cm}$} \\
\hline & & & & & $n$ boxcores & $\varnothing(\mathrm{cm})$ & \\
\hline \multirow[t]{3}{*}{$\bar{A}$} & $26-10-93$ & $49^{\circ} 28.98^{\prime}$ & $11^{\circ} 07.97^{\prime}$ & 208 & & & \\
\hline & 23-5-'94 & $49^{\circ} 29.7^{\prime}$ & $11^{\circ} 08.4^{\prime}$ & 208 & 3 & 30 & 2060.6 \\
\hline & $18-8-95$ & $49^{\circ} 28.52^{\prime}$ & $11^{\circ} 12.45^{\prime}$ & 231 & 3 & 30 & 2120.7 \\
\hline \multirow[t]{3}{*}{ I } & 19-10-'93 & $49^{\circ} 24.72^{\prime}$ & $11^{\circ} 31.86^{\prime}$ & 670 & 1 & 50 & 1963.5 \\
\hline & 23-5-'94 & $49^{\circ} 24.9^{\prime}$ & $11^{\circ} 31.4^{\prime}$ & 670 & 2 & 30 & 1413.7 \\
\hline & $19-8-95$ & $49^{\circ} 24.70^{\prime}$ & $11^{\circ} 31.86^{\prime}$ & 693 & 2 & 50 & 3927.0 \\
\hline \multirow[t]{3}{*}{ B } & $20-10-193$ & $49^{\circ} 21.99^{\prime}$ & $11^{\circ} 48.09^{\prime}$ & 1034 & 1 & 50 & 1963.5 \\
\hline & $24-5-194$ & $49^{\circ} 22.4^{\prime}$ & $11^{\circ} 45.1^{\prime}$ & 1034 & 2 & 50 & 3927.0 \\
\hline & 20-8-'95 & $49^{\circ} 22.00^{\prime}$ & $11^{\circ} 47.99^{\prime}$ & 1021 & 3 & 50 & 4339.4 \\
\hline \multirow[t]{3}{*}{$\|$} & 21-10-'93 & $49^{\circ} 11.20^{\prime}$ & $12^{\circ} 49.18^{\prime}$ & 1425 & 1 & 50 & 1963.5 \\
\hline & 26-5-'94 & $49^{\circ} 11.3^{\prime}$ & $12^{\circ} 49.7^{\prime}$ & 1425 & 2 & 50 & 3927.0 \\
\hline & $21-8-95$ & $49^{\circ} 11.19^{\prime}$ & $12^{\circ} 49.17^{\prime}$ & 1457 & 3 & 50 & 4417.9 \\
\hline \multirow[t]{3}{*}{$F$} & $25-10-93$ & $49^{\circ} 09.06^{\prime}$ & $13^{\circ} 05.40^{\prime}$ & 2182 & 1 & 50 & 1963.5 \\
\hline & 28-5-'94 & $49^{\circ} 09.5^{\prime}$ & $13^{\circ} 05.3^{\prime}$ & 2254 & 2 & 50 & 3769.9 \\
\hline & 22-8-'95 & $49^{\circ} 09.06^{\prime}$ & $13^{\circ} 05.38^{\prime}$ & 2256 & 3 & 50 & 4339.4 \\
\hline \multirow[t]{2}{*}{ III } & 30-5-'94 & $49^{\circ} 05.2^{\prime}$ & $13^{\circ} 25.9^{\prime}$ & 3673 & $2+1$ & $50+30$ & 4633.8 \\
\hline & 23-8-'95 & $49^{\circ} 03.99^{\prime}$ & $13^{\circ} 25.84^{\prime}$ & 3648 & 3 & 50 & 4417.9 \\
\hline \multirow[t]{2}{*}{$E$} & $1-6-194$ & $49^{\circ} 02.3^{\prime}$ & $13^{\circ} 42.2^{\prime}$ & 4460 & $2+1$ & $50+30$ & 4633.8 \\
\hline & 24-8-'95 & $49^{\circ} 02.29^{\prime}$ & $13^{\circ} 42.20^{\prime}$ & 4470 & 3 & 50 & 4339.4 \\
\hline
\end{tabular}

ture of benthic and benthopelagic communities. On the other hand, Scheltema (1994) suggests that activity of some epi- and infaunal deposit-feeding benthic species may contribute to the resuspension of particulate material into the nepheloid layer, thereby confounding the seasonal 'signal' of organic flux at or near the bottom. Seasonal reproduction has been demonstrated in some echinoderms (Tyler, 1986; Tyler \& Gage, 1984) and in some nuculanid protobranch species (Tyler et al., 1992) in the Rockall Trough and has been related to the seasonal input of organic material to the deep-sea.

The OMEX transect is located close to the Porcupine Seabight and the Rockall Trough and evidence for seasonal input could therefore be expected. We sampled seven stations along the OMEX transect $(208$ to $4470 \mathrm{~m})$ during three different seasons (spring, summer and autumn). The purpose was to find evidence for the seasonal input of organic material, to determine whether differences in input along the slope exist and how these are related to differences in the structure of benthic infauna communities.

\section{MATERIAL AND METHODS}

Seven stations (A, I, B, II, F, III, E) were sampled along the OMEX transect in three different seasons, autumn (October 1993), spring (May 1994) and summer (August 1995). The OMEX transect is situated in the Goban Spur area in the NE Atlantic. Samples were taken from the continental shelf of the Celtic Sea and along the continental slope down to the Porcupine Abyssal Plain, at water depths ranging from 208 to $4470 \mathrm{~m}$. Fig. 1 shows the depth profile of the OMEX transect, and temperature, salinity and oxygen content of the bottom water. In Table 1 the sampling dates, positions and water depths are given for the seven stations.

Macrofauna samples were taken with the circular boxcorer of the Netherlands Institute for Sea Research (NIOZ). No samples were taken at the shallowest station $A$ and the deepest stations III and $E$ in October 1993. Boxcores with a diameter of $30 \mathrm{~cm}$ (mainly from the shallowest stations) and $50 \mathrm{~cm}$ were used (Table 1). Some subsamples were taken out of some of the boxes for other purposes, resulting in dif- 
ferent sample sizes (Table 1). For this reason mean numerical densities and biomass values are given per $\mathrm{m}^{2}$ (but see Fig. 2. for sample variability).

Boxcore-samples were sliced in sediment layers of $0-5,5-10 \mathrm{~cm}$ in $1993,0-1,1-5,5-10,10-15 \mathrm{~cm}$ in 1994 and in 0-1, 1-3, 3-5, 5-10, 10-15 cm in 1995. Samples were sieved on a $0.5 \mathrm{~mm}$ mesh width, stored in $4 \%$ buffered formaldehyde, stained with Rose Bengal and sorted under a stereo microscope (10x). Biomass was estimated as wet weight per major taxon after drying the animals a few seconds on absorbent paper. Weighing was done with $0.1 \mathrm{mg}$ accuracy. Because of the small size of most individuals no attempt was made to puncture shells of bivalves to drain them of water. Biomass values were converted into organic $\mathrm{C}$-content per major taxon using the conversion factors given by Rowe (1983) For the macrofaunal-sized Nematoda a conversion factor of $6.1 \%$ (instead of $3.2 \%$ ) was used. Nematoda are usually considered to be a meiofaunal taxon and are therefore excluded from the macrofaunal data-set, but data on macrofaunal sized nematodes are given separately.

The respiration of the macrofaunal community was estimated after Mahaut et al. (1995) in two steps: via individual respiration

$$
R=0.0074 \times W^{-0.24}
$$

in which $R=$ individual respiration rate $\left(\right.$ day $\left.^{-1}\right)$, and $W=$ mean individual weight (mg organic $C$ ),

to community respiration $=\mathrm{B} \times \mathrm{R}$ (mg organic $\mathrm{C} \cdot \mathrm{m}^{-2} \mathrm{~d}^{-1}$ ), in which $\mathrm{B}=$ biomass $\left(\mathrm{mg}\right.$ organic $\mathrm{C} \cdot \mathrm{m}^{-2}$ ).

Respiration of large individuals was estimated separately and afterwards added to respiration of the macrofaunal community. Respiration of macrofaunal-sized Nematoda was also estimated separately. The estimation by Mahaut et al. (1995) was for deep-sea conditions with temperatures between 2 and $4{ }^{\circ} \mathrm{C}$. Because temperatures at the upper slope stations along the OMEX transect $(A, 1$, $B$, and II) were higher $\left(10.51,9.97,8.69\right.$, and $7.00^{\circ} \mathrm{C}$, respectively), corrections for temperature were made using Krogh's 'normal curve' (Winberg, 1971).

The data were analysed with ANOVA on log $(x+1)$-transformed density and biomass data per replicate box per year.

Small subcores of $10 \mathrm{~cm}$ diameter were taken out of the boxcores for sediment analysis. In 1993 and 1994 samples were sliced in different sediment layers to a depth of $15 \mathrm{~cm}$ for grain-size analysis. Because in both years very homogeneous sediments were found (Heip et al., 1994, 1995; Flach \& Heip, 1996), only one mixed sample per station was analysed in 1995. Particle size of the sediments was estimated using a Malvern Particle Sizer 3600 EC. Also for carbon and nitrogen analysis small subcores were sliced in different sediment layers in 1993 and 1994 (Heip et al, 1994, 1995; Flach \& Heip, 1996). Because seasonal variation in the input in organic matter would mainly influence the upper layer of the sediment, only the upper $1 \mathrm{~cm}$ of the sediment, sliced in layers of 2.5 $\mathrm{mm}$, and one deeper layer $(9-10 \mathrm{~cm})$ as a control, were analysed in 1995 . These samples were immediately frozen at $-25^{\circ} \mathrm{C}$ on board and analysed with a Carlo Erba type NA-1500 elemental analyzer according to Nieuwenhuize et al. (1994). Carbon was partitioned in organic and inorganic fractions by acidification with $25 \% \mathrm{HCl}$ in situ in silver sample cups.

\section{RESULTS}

\subsection{MACROFAUNA}

\section{a. Density}

Macrofauna density showed an exponential decrease with increasing water depth (Fig. 2a). Fig. 2a also shows that the differences between the replicate boxes were relatively small. The regression lines for all three years were highly significant $(p<0.005$ for 1993 and $p<0.001$ for both 1994 and 1995). The slope of the regression line for August 1995 was significantly (ANOVA, depth*year $p=0.009$ ) less steep than for May 1994, which indicates a difference between the seasons/years. These differences are shown in more detail in Fig. 3. On the upper part of the slope to a depth of $-1500 \mathrm{~m}(\mathrm{~A}, \mathrm{I}, \mathrm{B}$, and II) macrofauna densities were significantly $(p<0.05)$ higher in May and than in August and October. No significant differences between the years were observed at the lower slope stations ( $F$, III, and $E)$, although at the deeper stations $F(\sim 2200 \mathrm{~m})$ and $\mathrm{III}(\sim 3650 \mathrm{~m})$ densities were somewhat higher in August. At the deepest station E $(\sim 4460 \mathrm{~m})$ densities were similar in May and August. The marked differences in density between May and August on the upper part of the slope, were mainly a result of large numbers of small (juvenile) echinoderms in May (Fig. 3). Densities of Echinodermata were significantly $(p<0.001)$ higher in May than in August at the four upper-slope stations, but were not significantly different between May and August at the lower-slope stations. At the shallowest st. A (208 $\mathrm{m})$ the difference was caused mainly by juvenile echinoids (both Spatangidae and Echinus spp.), whereas at the stations I, B and II mainly postlarvae of the ophiuroid Ophiocten gracilis were responsible (Fig. 4). In August 1995 hardly any small echinoderms were found at these stations. At st. F low densities of postlarvae of Ophiura ljungmani were found both in May 1994 and in August 1995, whereas at the deeper stations $\mathrm{III}$ and $E$ they were only found in August 1995. Adult O. ljungmani were found at all three deep stations in both years, whereas adult $O$. gracilis were found at stations I, B and II during all seasons.

Crustacea became relatively more abundant within the macrofaunal community with increasing water 


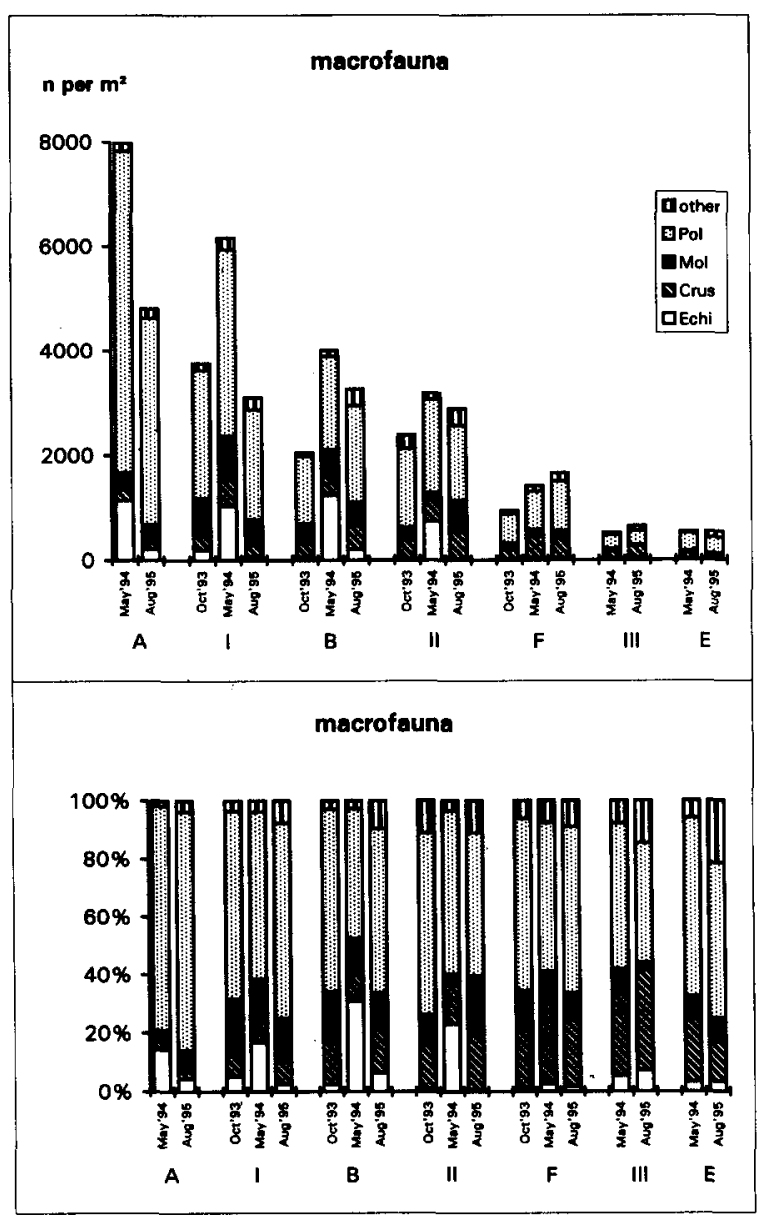

Fig. 3. Macrofaunal densities $\left(n \cdot m^{-2}\right)$ and the relative abundance of the major taxonomic groups along the OMEX transect (the seven stations A to E) in October 1993, May 1994, and August 1995. Echi $=$ Echinodermata, Crus = Crustacea, $\mathrm{Mol}=$ Mollusca, $\mathrm{Pol}=$ Polychaeta, other $=$ all other small taxa.

depths (Fig. 3). Absolute numbers, however, were largest at mid-slope depths (Fig. 5). At the mid-slope stations B and II densities of Crustacea were significantly $(p<0.05)$ higher in August than in other months, whereas at the shallow stations $A$ and I their densities were highest in May, though not significantly so $(p=0.14)$. Decapods were only found at st. $A$, and the two females of Callianassa sp. found in May had large numbers of juveniles (127 and 142) in their broodpouch. The taxonomic composition of the crustacean populations showed clear depth-gradients. Amphipods decreased in relative abundance with increasing water depth, whereas isopods increased. Cumaceans were most abundant at mid-slope depths $(\sim 1000$ to $\sim 1500 \mathrm{~m})$. This pattern was quite similar during all three seasons and years. Many crusta-

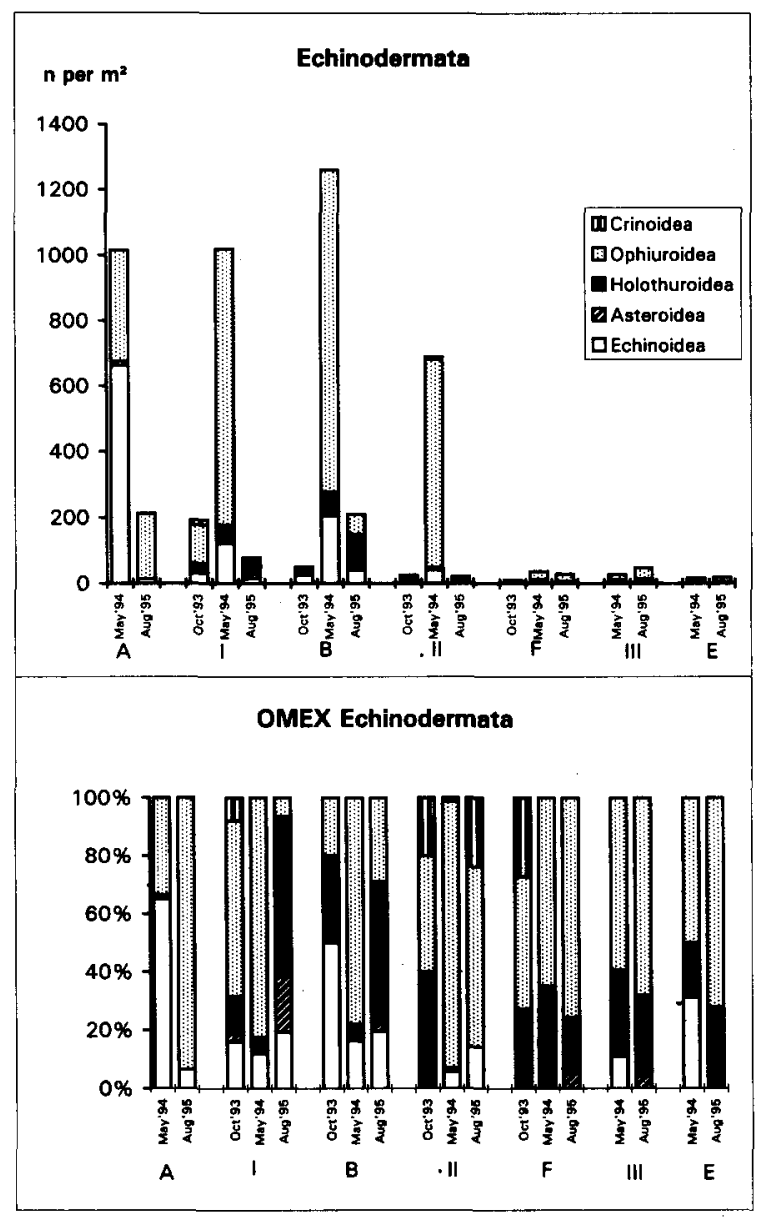

Fig. 4. Echinodermata densities $\left(n \cdot m^{-2}\right)$ and relative abundance of the taxa along the OMEX transect (the seven stations A to E) in October 1993, May 1994, and August 1995.

ceans show brood-care and a few tanaids, isopods and amphipods with low numbers (2-10) of eggs or juveniles in their broodpouch were found at stations I, $B, I I$ and $F$ in all seasons.

The relative abundance of molluscs within the macrofaunal community was fairly stable $(\sim 10 \%$, Fig. 3$)$. Most of the molluscs were bivalves, which did not show any significant seasonal pattern (Fig. 6). At st. B and especially at st. II large numbers of gastropods were found (Fig. 6). The very large numbers in August 1995 at st. II were a result of just one species, the deposit-feeder Benthonella tenella.

Polychaetes were the most abundant taxon at all stations and during all years (Fig. 3). Their absolute numbers decreased with increasing water depth (Fig. 7). At the shallowest stations $A$ and $I$, numbers were significantly $(p<0.05)$ larger in May than in August, 


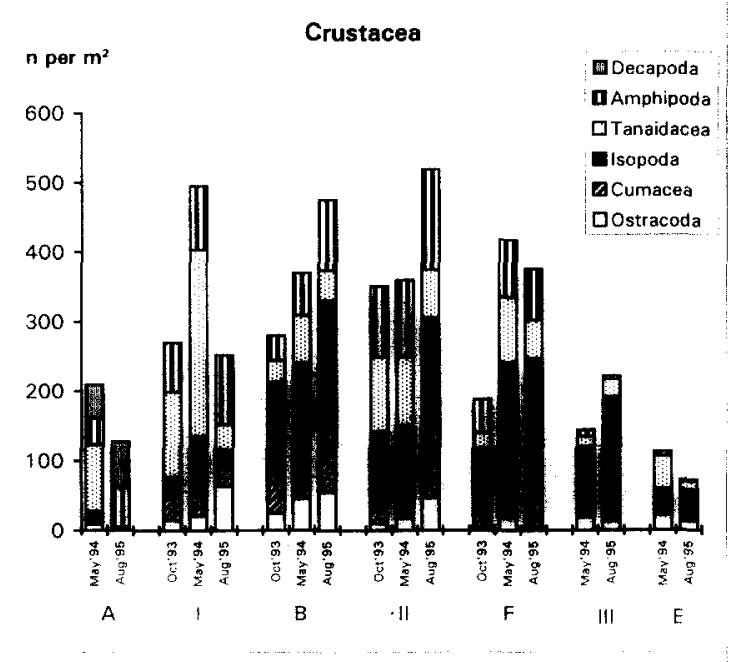

OMEX Crustacea

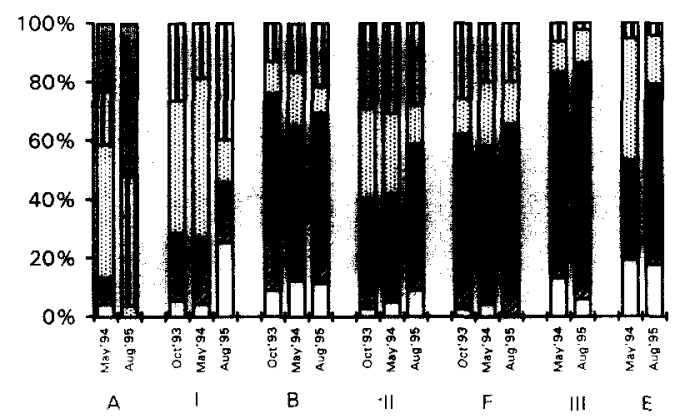

Fig. 5. Crustacea densities $\left(n \cdot m^{-2}\right)$ and relative abundance of the taxa along the OMEX transect (the seven stations $A$ to $E$ ) in October 1993, May 1994, and August 1995.

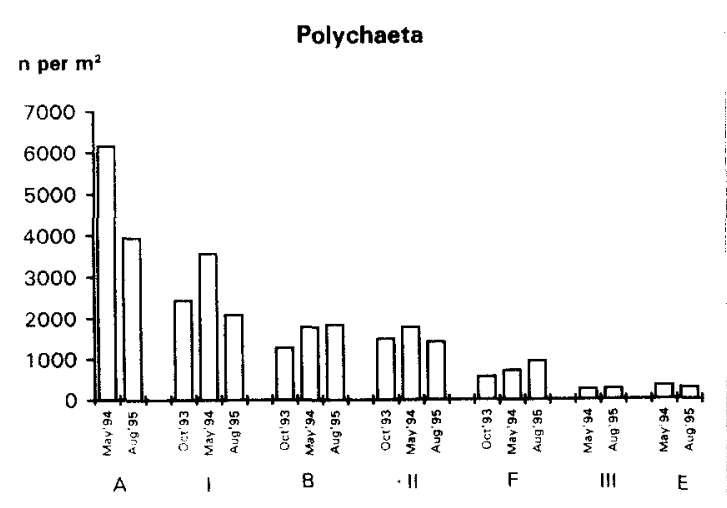

Fig. 7. Polychaeta densities $\left(n \cdot m^{-2}\right)$ along the OMEX transect (the seven stations A to E) in October 1993, May 1994, and August 1995.

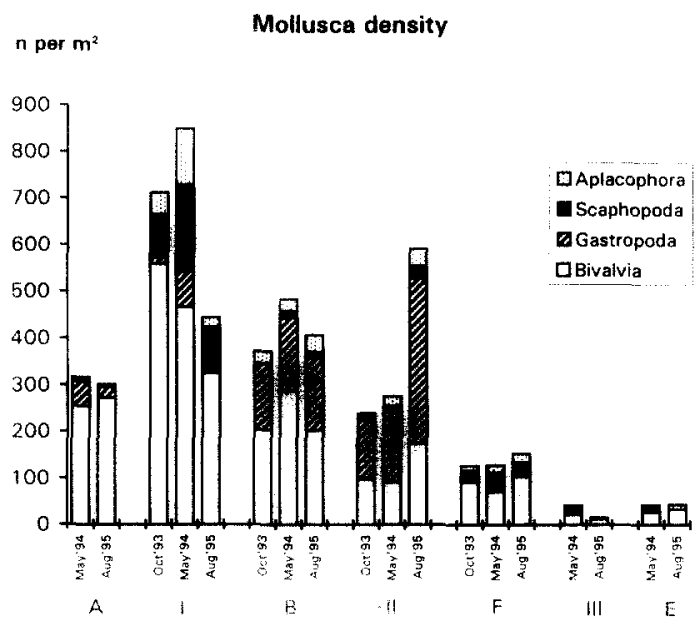

Mollusca density

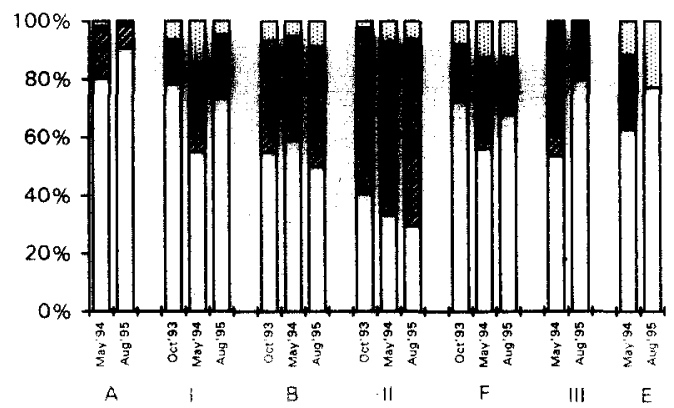

Fig. 6. Mollusca densities $\left(n-m^{-2}\right)$ and relative abundance of the taxa along the OMEX transect (the seven stations $A$ to $E$ ) in October 1993, May 1994, and August 1995.

and also at st. II ( $1450 \mathrm{~m})$ numbers were somewhat larger in May. At st. F, on the other hand, polychaete numbers were somewhat higher in August.

The small fraction of other taxa given in Fig. 3 mainly consisted of Sipuncula, Nemertini, and (especially at st. II) Porifera and Tunicata.

\section{b. Biomass}

Biomass values along the OMEX transect also decreased with increasing water depth, although relatively high biomass values were found at st. $B$ and low values at st. II during all three years (Fig. 2b). Extremely large individuals were excluded from biomass data. When they are included, the highest biomass values were found at st. $B$ in May with $\sim 1650$ $\mathrm{mg}$ organic $\mathrm{C} \cdot \mathrm{m}^{-2}$ (mainly due to 1 Pennatulacea +1 Sipuncula) and at st. A in August with $\sim 1200 \mathrm{mg}$ organic $\mathrm{C} \cdot \mathrm{m}^{-2}$ (mainly because of 2 Echinoidea). Fig. $2 \mathrm{~b}$ also shows that the differences in biomass (with- 
out large ind.) between the replicate boxes were somewhat larger than in density, but the slopes of the regression lines for 1994 and 1995 were still highly significant $(p<0.001)$. Overall, no significant differences in the slope (ANOVA, depth ${ }^{\star}$ year $p=0.28$ ) were found between the years, nor a significant difference between the $y$-intercepts $(p=0.08)$. However, Fig. 8 shows that biomass values were somewhat higher in May at the three shallowest stations $A, I$ and $B$, and higher in August at the mid-slope stations II and $F$. Echinoderms were relatively important at nearly all stations, except at st. $F$ where the biomass was dominated by the polychaetes and molluscs. The relatively high biomass value of the group of 'other taxa' was mainly caused by relatively large deposit-feeding sipunculids, although the three largest sipunculids found at st. B in May and October and at st. E in August were excluded. Crustaceans were relatively

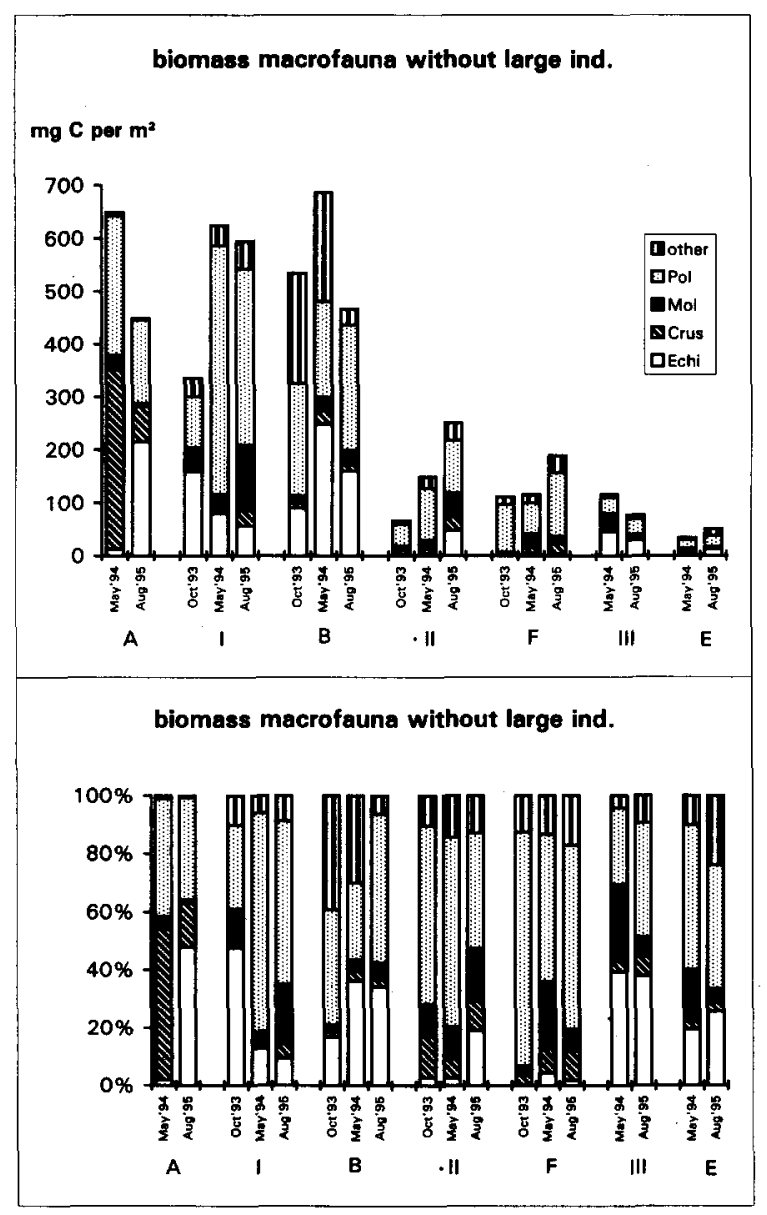

Fig. 8. Macrofauna biomass with exclusion of some extremely large individuals (mg organic $\mathrm{C} \cdot \mathrm{m}^{-2}$ ) and the relative biomass of the major taxonomic groups along the OMEX transect (stations A to E) in October 1993, May 1994, and August 1995 . Echi $=$ Echinodermata, Crus = Crustacea, Mol $=$ Mollusca, Pol = Polychaeta, other = all other small taxa.

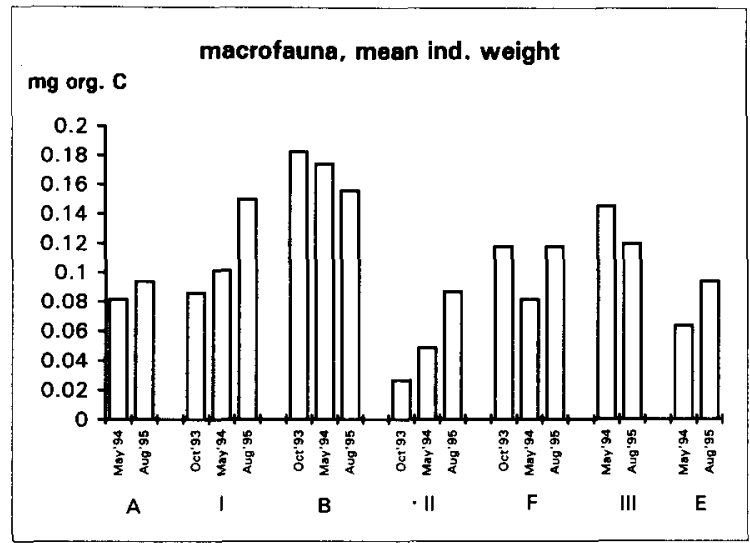

Fig. 9. Mean individual weight (mg organic $\mathrm{C}$ ) of the major taxa along the OMEX transect (the seven stations $A$ to $E$ ) in October 1993, May 1994, and August 1995.

unimportant in biomass, except for Callianassa, found at st. A in May. Fig. 9 shows that there were no significant differences in mean individual weight for total macrofauna between the seasons and years. Mean individual weights were highest at st. B and lowest at st. II on all three sampling occasions.

\section{c. Vertical distribution within the sediment}

Not much is known about vertical distribution within the sediment during October 1993, because only two depths layers were taken and nearly all macrofauna $(\sim 90 \%)$ was found in the upper $5 \mathrm{~cm}$ of the sediment. In May 1994 a clear pattern was found with the highest proportion of the animals in the upper $1 \mathrm{~cm}$ of the sediment at intermediate depths and relatively lower proportions at both the shallow and deep stations (Fig. 10) (Flach \& Heip, 1996). In August 1995 a more or less similar pattern was found. Again the highest proportions of the macrofauna were found in the upper $1 \mathrm{~cm}$ of the sediment at st. B and st. II and the decline in the shallow part of the transect was still present. The lower proportions in 1995 than in 1994 in the upper $1 \mathrm{~cm}$ was due to the virtual absence in 1995 of juvenile echinoderms found in high densities in May 1994. However, at the deepest stations III and E somewhat larger numbers were found in the upper $1 \mathrm{~cm}$ in August than in May. This pattern was observed in all three replicate boxes.

\subsection{MACROFAUNAL NEMATODA}

Densities of $\sim 100$ to 600 nematodes per $\mathrm{m}^{2}$ were found in the macrofaunal samples. They were found to a depth of 10 to $15 \mathrm{~cm}$ in the sediment, although most of them were found in the upper layers of the sediment (Fig. 11). Significant $(p<0.01)$ differences in densities of Nematoda were found between the two years. Largest numbers of large nematodes were found at mid-slope depths, especially at st. B. The nematodes at st. B were mainly found below the 
macrofauna 1994
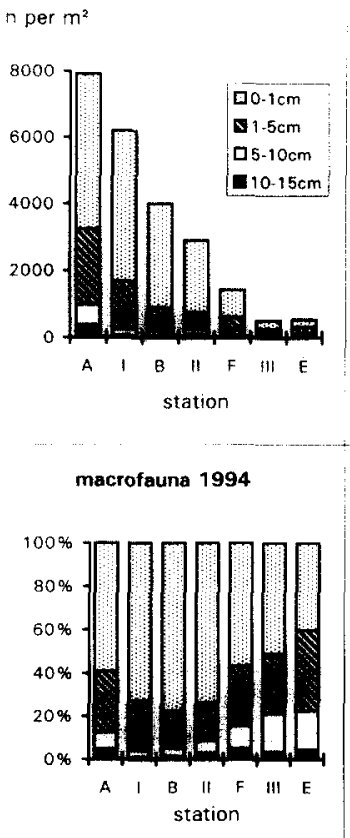

macrolauna 1995

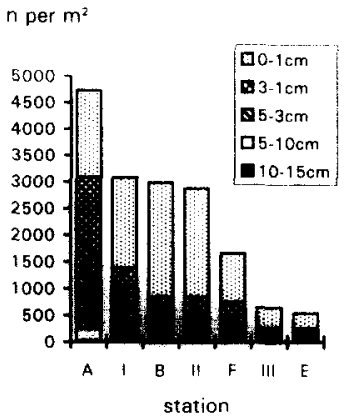

macrofauna 1995

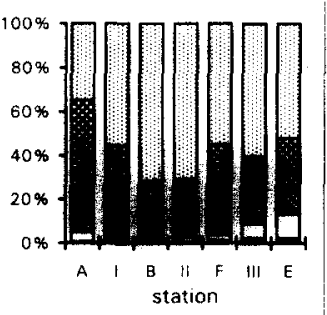

Fig. 10. Macrotauna densities $\left(n \cdot m^{-2}\right)$ and relative abundance in the different sediment layers $(\mathrm{cm})$ along the OMEX transect (the seven stations A to E) in May 1994, and August 1995.

macrofaunal Nematoda, mean ind. weight

mg org. C

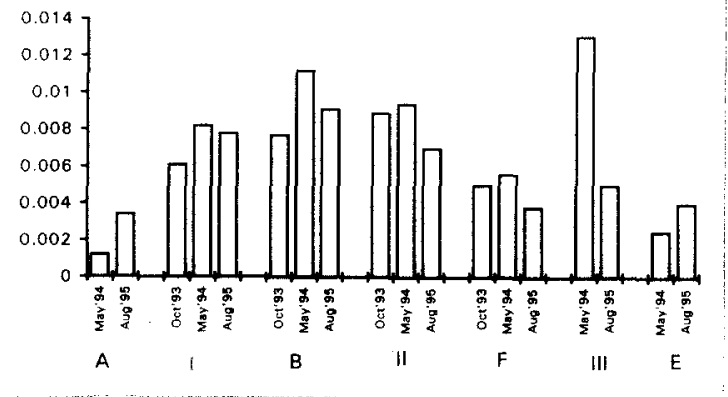

Fig. 12. Mean individual weight (mg organic $\mathrm{C}$ ) of macrofaunal-sized Nematoda along the OMEX transect (the seven stations A to E) in October 1993, May 1994, and August 1995.

upper $1 \mathrm{~cm}$ of the sediment, whereas the macrofauna was mainly concentrated in the upper $1 \mathrm{~cm}$. Not only were numbers large at st. B, but mean individual weights were also high (Fig. 12). No significant differ-

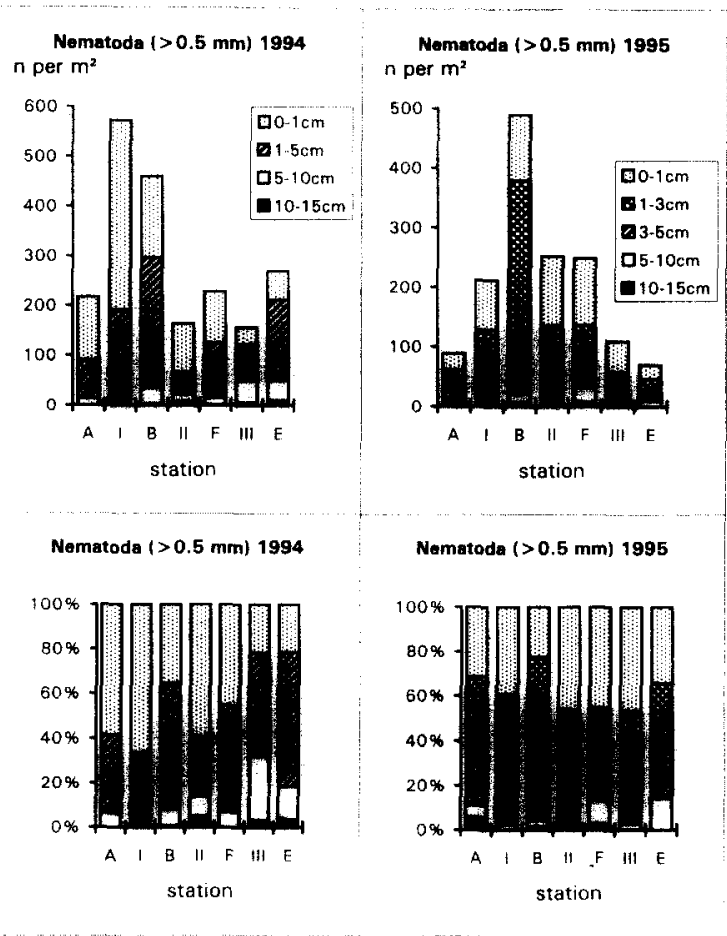

Fig. 11. Densities $\left(n \cdot \mathrm{m}^{-2}\right)$ and relative abundance of macrofaunal sized Nematoda in the different sediment layers $(\mathrm{cm})$ along the OMEX transect (the seven stations $A$ to $E$ ) in May 1994, and August 1995.

ences in mean individual weights or biomass values were found between the years (seasons).

\subsection{RESPIRATION}

Fig. 13a shows the calculated respiration of total macrofauna in the three different seasons. Respiration was high $\left(15\right.$ to $\left.20 \mathrm{mgC} \cdot \mathrm{m}^{-2} \cdot \mathrm{d}^{-1}\right)$ in May at the three shallowest stations $(A, I$ and $B$ ) and much lower ( 1 to $3 \mathrm{mgC} \cdot \mathrm{m}^{-2} \cdot \mathrm{d}^{-1}$ ) at the deeper stations. At the three shallowest stations ( 200 to $\sim 1000 \mathrm{~m})$ respiration was highest in May, whereas at the mid-slope stations $(\sim 1400-2200 \mathrm{~m})$ respiration was higher in August. At the deepest stations ( $3600-4500 \mathrm{~m})$ respiration was more or less uniform $\left(\sim 1 \mathrm{mgC} \cdot \mathrm{m}^{-2} \cdot \mathrm{d}^{-1}\right)$.

Fig. $13 b$ shows that macro-nematode respiration was highest at the upper slope stations $I$ and B. Respiration was somewhat higher in May at most stations, except at st. II where it was more or less similar during all three seasons. At the shelf station $A$ macro-nematode respiration was very low $(\sim 0.02$ $\mathrm{mgC} \cdot \mathrm{m}^{-2} \cdot \mathrm{d}^{-1}$ ) and only responsible for $\sim 0.1 \%$ of total macrofaunal $(>0.5 \mathrm{~mm}$ ) respiration, in contrast to $\sim 2$ to $3 \%$ of total macrofaunal respiration at the lower-slope stations II to $E$. 


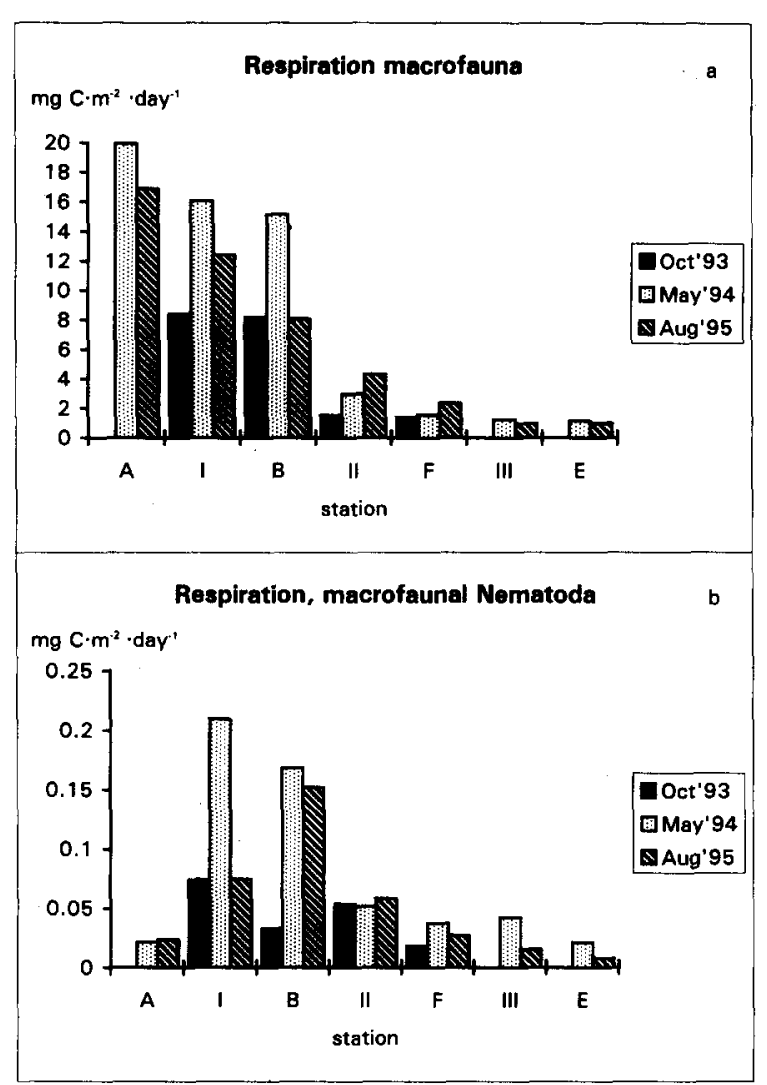

Fig. 13. Respiration (mg C.m $\mathrm{m}^{-2} \cdot \mathrm{d}^{-1}$ ) of (a) the macrotauna sensu stricto and (b) the macro-nematodes along the OMEX transect during the three different seasons. Respiration calculated after Mahaut et al. (1995). Note the different scales of (a) and (b).

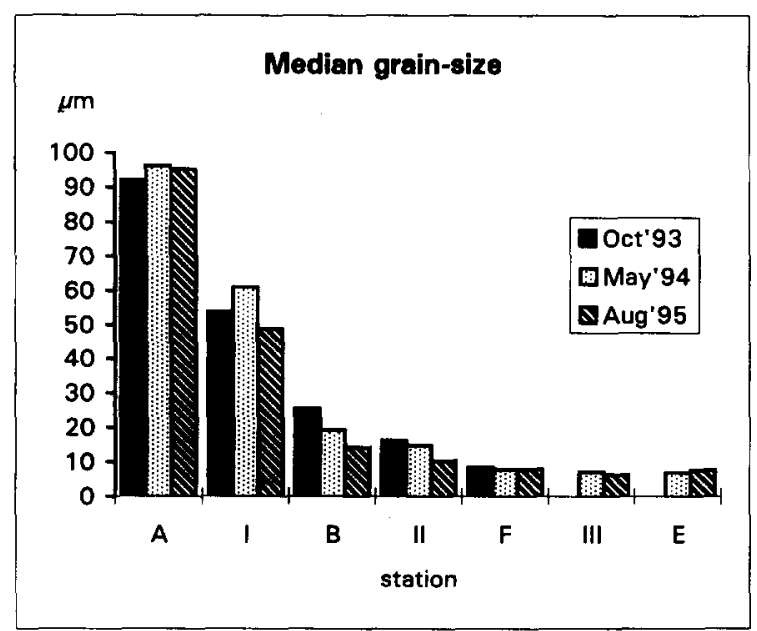

Fig. 14. Median grain-size $(\mu \mathrm{m})$ in the upper $5 \mathrm{~cm}$ of the sediment along the OMEX transect (the seven stations $A$ to $E$ ) in October 1993, May 1994, and August 1995.

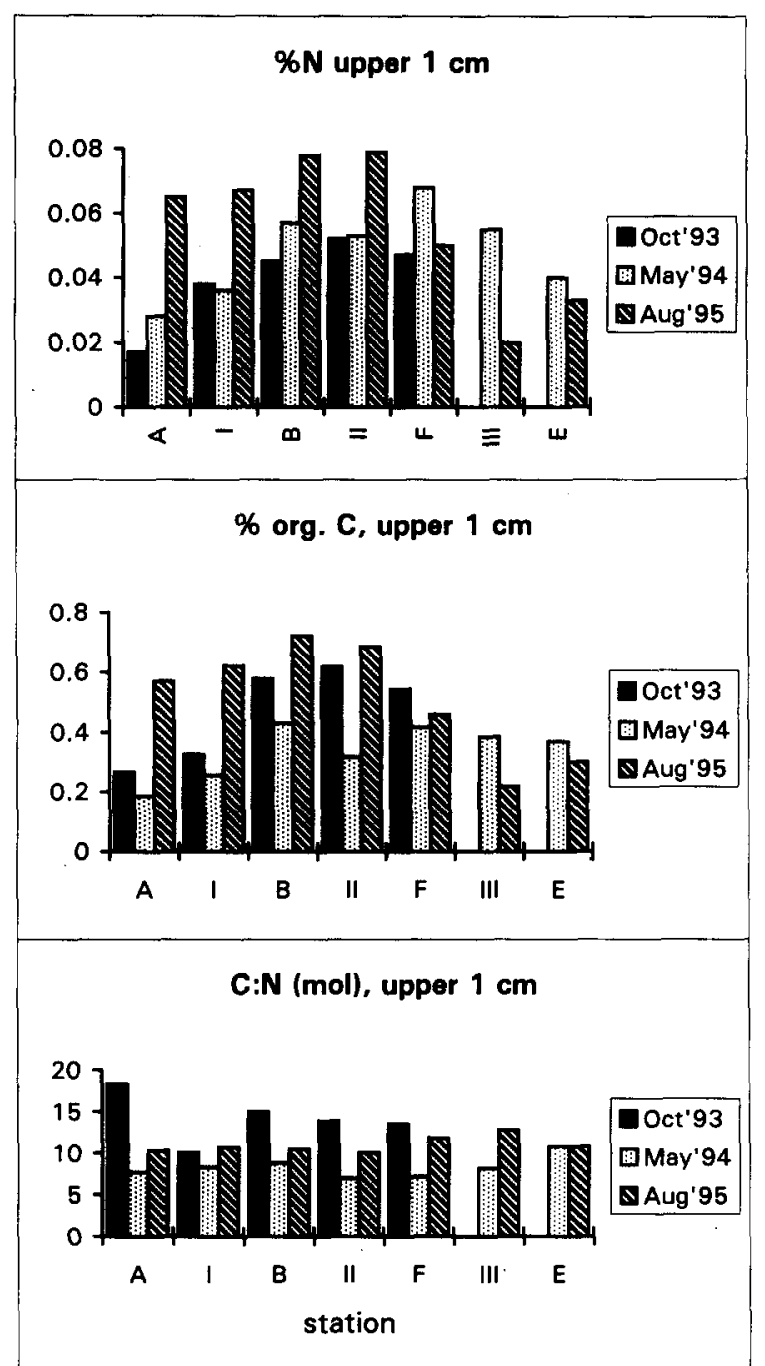

Fig. 15. Total nitrogen $(N)$ and organic carbon $(C)$ as a percentage of the sediment, and the $\mathrm{C}: \mathrm{N}$ ratio (mol) in the upper $1 \mathrm{~cm}$ of the sediment along the OMEX transect (the seven stations A to E) in October 1993, May 1994, and August 1995.

\subsection{ABIOTIC PARAMETERS}

Median grain size along the OMEX transect decreased with increasing water depth from $\sim 95 \mu \mathrm{m}$ at st. $A$ to $\sim 8 \mathrm{~mm}$ at st. $F$, after which it remained constant (Fig. 14). Grain size did not show any significant difference between the seasons.

The percentage of organic carbon and total nitrogen showed a clear seasonal pattern (Fig. 15). At the upper part of the slope to a depth of $\sim 1500 \mathrm{~m}$ significantly higher percentages of organic $C(p=0.001)$ and $N(p<0.001)$ were found in August 1995 than in October or May. This percentage was highest at st. B. In 
particular the percentage of organic $\mathrm{C}$ was lower in October; in May it was even lower. At the lower-slope stations, the percentage of $\mathrm{N}$ was significantly $(p=0.05)$ higher in May, whereas the percentage of organic $C$ was not significantly different between the seasons. However, at st. $F$ the percentage of organic $\mathrm{C}$ was somewhat higher in October and again lower in May. Unfortunately, no data are available for the two deepest stations in October, but here the pattern has changed: somewhat higher values were found in May. The C:N ratio was significantly $(p<0.001)$ different between the seasons at the upper and middle part of the slope (stations $A$ to $F$ ). The $\mathrm{C}: \mathrm{N}$ ratio (mol) was lowest in May ( $\sim 7$ to 8$)$, higher in August ( $\sim 10$ to 12) and even higher in October $(-14$ to 17$)$ in the upper $1 \mathrm{~cm}$ of the sediment (Fig. $15 \mathrm{c}$ ). The C:N ratio at the deepest st. E was similar ( 11) in May and August.

\section{DISCUSSION}

\subsection{NUMERICAL DENSITIES}

Although the usual trend of exponential decrease in macrofaunal densities with increasing water depths was observed in all three years, differences between the years were also observed (Fig. 2). The most striking difference was the large number of small echinoderms at the upper part of the slope in May 1994. The majority were postlarvae of the bathyal species Ophiocten gracilis. This species is known to be a seasonal breeder of which postlarvae were found in the Rockall Trough in midwater plankton samples in March/April and on the sediment from late May to August/September (Gage \& Tyler, 1981, 1982a). These authors found them at 2200 and $2900 \mathrm{~m}$ water depth, whereas along the OMEX transect they were only found in the upper part of the slope to a depth of $-1500 \mathrm{~m}$. Below this depth low densities were found of postlarvae of another ophiuroid species, Ophiura ljungmani. This species, living in the upper abyssal, also reproduces annually in early spring and recruitment of postlarvae occurs during summer (Gage \& Tyler, 1982b). The numbers of postlarvae of $O$. ljungmani were somewhat larger in August 1995 than in May 1994 at station F, and only in August were postlarvae found at the deeper stations III and E. On the other hand, in August 1995 only two very small postlarvae of $O$. gracilis were found at st. $B$, and one somewhat bigger at st. II. This will indicate year-to-year variability rather than seasonal variation. Gage \& Tyler (1982b) also reported variation in both timing and magnitude of recruitment between years. Gage \& Tyler (1982a and b) propose that the seasonal reproduction in these two species is controlled by annual variation in flux of fast sinking detrital food from the surface.

Lampitt (1985) reported great differences in timing of the spring bloom between 1982 and 1983 in the
Porcupine Seabight. in 1982 the bloom occurred in early April and the detritus reached a depth of $2000 \mathrm{~m}$ on 1 May, whereas in 1983 the bloom did not occur until mid-May and detritus reached a depth of $4000 \mathrm{~m}$ in mid-June. Rice et al. (1994) also reported a considerable year-to-year variability in the timing of the maximum of the phytodetritus flux. Time-lapse photography at an abyssal $(4800 \mathrm{~m})$ site in the Porcupine Abyssal Plain showed phytodetritus at the sea floor on 16 May 1991, and in 1992 a massive influx of material occurred in the second half of May. In 1993 deposition began rather later (5/6 June) and was apparent for a shorter time on the bottom than in 1991 and 1992. This late arrival of the detritus can have (major) effects on both the survival of the postlarvae and on the development of the gonads. Pearson \& Gage (1984) found in $O$. gracilis a marked decrease in the proportion of stomachs containing food in summer, which coincided with seasonal gonadal development. They conclude that $O$. gracilis ingests sufficient food in spring to provide for both reproductive and somatic growth during the rest of the year. A different reproductive strategy, which could be favourable when food availability is variable, is shown by the ophiuroid Ophiomusium lymani. This species shows no reproductive periodicity, but a seasonal recruitment as a direct response to seasonal sedimentation of organic matter enhancing the survival of the newly settled larvae (Gage \& Tyler, 1982c).

At the shallowest st. A, in addition to small ophiuroids, large numbers of small echinoids were found in May 1994. These were not present in August 1995. These small echinoids were both Spatangidae and Echinus species. Echinus affinis is known to breed seasonally (Tyler et al., 1994) and also to forage actively for detrital accumulations (Billett et al., 1983). Correlations between feeding mode and reproductive strategies were also shown for two sympatric species of seastars (Tyler et al., 1993) and some bivalves (Tyler et al., 1992). Along the OMEX transect no evidence for seasonal variation in bivalve density was found. Scheltema (1994), in an overview of reproductive strategies in molluscs, concludes that most molluscan species reproduce continuously and show no seasonal periodicity. The only gastropod of which larvae were actually found at the sea surface is Benthonella tenella (Scheltema, 1994). This species was found in large numbers at the OMEX stations $B$ and II, and in much larger numbers (especially at st. II) in August 1995 than in May 1994 and October 1993, thus indicating seasonal variation. Blake \& Watling (1994) studied reproduction of three abundant species along the continental slope off Massachusetts and found no evidence for seasonal recruitment. An aplacophoran mollusc from mid-slope depths reproduced continuously, a cumacean from the lower continental slope showed variable but constant recruitment and a deep-sea spionid (1250 to 
$2100 \mathrm{~m}$ ), although exhibiting seasonality in egg production, showed no seasonality in recruitment. Along the OMEX transect polychaete numbers were significantly higher in May at the shallowest stations (208, $670 \mathrm{~m}$ ), which could indicate seasonal recruitment. The fact that both females of Callianassa sp. had juveniles in their broodpouch in May at the shallow st. $A$ also suggests seasonal reproduction. Numbers of individuals per species were too low, however, to give reliable information about seasonal reproduction in these taxa. Gooday et al. (1996) found no direct response of metazoan meiofauna to phytodetritus at a bathyal site in the Porcupine Seabight. They did, however, find larger numbers of nauplii after arrival of the phytodetritus and suggest that a time-lagged response to sedimentation events in metazoans is possible.

\subsection{BIOMASS}

Stations $B$ and II were exceptional as to biomass values. At st. B, biomass values were relatively high owing to large animals, and at st. II biomass was low because of small individuals. A high biomass value at $\sim 1000 \mathrm{~m}$ water depth was also found in the Rockall Trough (Gage, pers. comm.) and Lampitt (1985) reported an elevated biomass of megabenthic suspension feeders between 900 and $1200 \mathrm{~m}$ in the Porcupine Seabight. Lampitt (1985) speculates that this high biomass could be a result of elevated detrital resuspension over a limited area. He found that near-bottom currents in excess of $7 \mathrm{~cm} \cdot \mathrm{s}^{-1}$ are necessary for resuspension. Indeed the highest current velocities along the OMEX transect, found at st. B and II (Graf \& Thomsen, 1995: Van Weering \& De Stigter, 1995), were higher than the $7 \mathrm{~cm} \cdot \mathrm{s}^{-1}$ necessary for resuspension. At these two stations relatively large numbers of filter-feeders and surface deposit-feeders were found (Heip et al., 1995; Flach \& Heip, 1996) and nearly all macrofauna was concentrated in the upper $1 \mathrm{~cm}$ of the sediment (Fig. 9). Current velocities along the OMEX transect were much higher in winter than in summer (Graf \& Thomsen, 1995) and always highest at stations II and B. Mesocosm experiments (Thomsen \& Flach, 1997) with three different flow velocities under winter (without suspended phytodetritus) and summer (with phytodetritus) conditions showed that during summer even under critical flow conditions with erosion, the macrofauna was able to reduce phytodetritus and $P O C$ from the $\mathrm{BBL}$ at 50 and $60 \%$ higher rates than occurred in sediments of similar bottom roughness without macrofauna. Organic carbon normally passing these mid-slope areas during high-flow conditions is trapped, accumulated and/or remineralized by the macrofauna. Beside high flow velocities bottom water characteristics are also different around $1000 \mathrm{~m}$ water depth, where a salinity maximum and an oxygen minimum occur (Fig. 1). This was also found in the Porcupine Seabight (Rice et al., 1991), where it characterized Mediterranean water.

\subsection{ORGANIC CARBON}

The total amount of organic $C$ in the upper $15 \mathrm{~cm}$ of the sediment showed a clear peak of $\sim 1650 \mathrm{mgC} \cdot \mathrm{m}^{-2}$ at st. B in May 1994, whereas at all other stations $\sim 400 \mathrm{mgC} \cdot \mathrm{m}^{-2}$ was found. The $\mathrm{C}: \mathrm{N}$ ratio was $\sim 7$ to 8 in May, indicating arrival of fresh phytodetritus from the surface. The increase in $\mathrm{C}: \mathrm{N}$ ratio in August and October indicates a rapid degradation of this material. In August gelatinous lumps ('aggregates') were found on top of the sediment along the OMEX transect. Very small amounts of this material were found at the upper part of the slope, but large amounts at the deeper part especially at st. III (3670 m). This material contained perdinin which is derived from dinoflagellates (De Wilde, NIOZ, pers. comm.). Gooday \& Lambshead (1989) report a 5-mm-thick layer of gelatinous lumps of phytodetritus from a bathyal site $(1320-1360 \mathrm{~m})$ in the Porcupine Seabight in July, which was absent in April. Lampitt (1985) found no evidence for a detrital carpet at the top of the continental slope, which he attributes to stronger currents or to higher benthic degradation at shallow depths. This could be caused by greater biological activity or because the material itself is more labile. Sinking particles degrade most rapidly in the upper $1000 \mathrm{~m}$. The higher proportions of organic $\mathrm{C}$ and $\mathrm{N}$ in the sediment at the upper part of the OMEX transect in August could indicate that the phytodetritus was intercepted by the fauna and buried in the sediment. The C:N ratios at stations $B$ and 11 were $\sim 7$ to 8 throughout the sediment column to a depth of $15 \mathrm{~cm}$ in May, also indicating a rapid burial of the fresh material in the sediment (Flach \& Heip, 1996). At the deeper stations lower densities of macrofauna were found, of which a higher proportion lived in the deeper sediment layers and consisted of subsurface deposit-feeders, than at the shallower stations (Flach \& Heip, 1996); this could result in an accumulation of the phytodetritus on top of the sediment. The higher proportion of animals found in the upper $1 \mathrm{~cm}$ of the sediment at the deepest stations III and E in August than in May could be a direct response to the input of phytodetritus, which was found in the largest amounts at these stations.

Gooday \& Turley (1990) conclude from the variations in colour and in the planktonic constituents of phytodetritus that several pulses may be deposited during late spring and summer. Most of the organic matter arriving on the ocean floor is rapidly utilized by benthic communities and only a small proportion enters the sedimentary record (Gooday \& Turley, 1990). Pfannkuche (1993) found a doubling of bacterial biomass between March and July at the BIOTRANS-station $(4560 \mathrm{~m})$. Annual sedimentation of phytodetritus at this station starts in late April-early May with a maximum in June-July. Sediment commu- 
nity oxygen consumption (SCOC) also showed a distinct seasonal maximum of $9 \mathrm{mg} \mathrm{C} \cdot \mathrm{m}^{-2} \cdot \mathrm{d}^{-1}$ in July-August. Both annual and interannual variation in sedimentation of phytodetritus was observed at this site. Lampitt et al. (1995) found a strong seasonal signal in the quantity of the phytodetritus in the Porcupine Seabight, but no significant seasonal variation in oxygen consumption was detected. Calculated respiration along the OMEX transect showed high values at the upper slope stations (A, I and B) in May and much lower values and a less pronounced seasonality at the lower part of the slope. On the (nearby) Mediadzek Terrace (Bay of Biscay) seasonal variation in deep-sea particle fluxes was found, with a maximum in May (Khripounoff \& Crassous, 1994). Organic carbon concentration as an indicator of particle quality was also higher in May $(9.5 \%)$ than during other months ( 3.5 to $5.5 \%$ ). At $2100 \mathrm{~m}$ water depth $200 \mathrm{~m}$ above the bottom an organic-C flux of 42 $\mathrm{mg} \cdot \mathrm{m}^{-2} \cdot \mathrm{d}^{-1}$ was found in May and only $3 \mathrm{mg} \cdot \mathrm{m}^{-2} \cdot \mathrm{d}^{-1}$ in August. Assuming that these values are applicable to the OMEX station $F(2182 \mathrm{~m}$ ), the influx of organic $C$ is much higher than used for respiration by the macrofauna in May, whereas in August nearly all of the organic $C$ input would be used by macrofaunal respiration $\left(2.39 \mathrm{mg} \cdot \mathrm{m}^{-2} \cdot \mathrm{d}^{-1}\right)$. However, Antia et al. (1995) found in sediment-traps deployed from July to December 1993 at the OMEX stations II and III, the highest influx of organic $C$ in August ( 20 and $\sim 10$ $\mathrm{mg} \cdot \mathrm{m}^{-2} \cdot \mathrm{d}^{-1}$, respectively). Calculated respiration rates of macrofauna at these stations in August were 4.39 and $0.98 \mathrm{mg} \cdot \mathrm{m}^{-2} \cdot \mathrm{d}^{-1}$, respectively, thus using $\sim 22 \%$ and $\sim 10 \%$ of the organic $C$ influx. On a yearly basis an input of $\sim 2.86 \mathrm{gC} \cdot \mathrm{m}^{-2}$ occurs at st. $\|$ and $\sim 2.19$ $\mathrm{gC} \cdot \mathrm{m}^{-2}$ at st. III. The the calculated macrofaunal respiration amounts to 1.09 and $0.41 \mathrm{gC} \cdot \mathrm{m}^{-2}$, i.e. $38 \%$ and $19 \%$ of the organic $\mathrm{C}$ input. At st. B the macrofaunal respiration is $\sim 3.8 \mathrm{gC} \cdot \mathrm{m}^{-2} \cdot \mathrm{y}^{-1}$. Assuming a vertical influx similar to that of st. II, this leads to a deficiency of $\sim 1 \mathrm{gC} \cdot \mathrm{m}^{-2} \cdot \mathrm{y}^{-1}$. Rice et al. (1991) calculated a carbon input from the primary production of 1.6 to 2.7 $\mathrm{gC} \cdot \mathrm{m}^{-2}$ at $1000 \mathrm{~m}$ in the Porcupine Seabight, which would be similar to the OMEX-B situation. In the same area, Lampitt et al. (1986) calculated a daily respiratory demand of $0.91 \mathrm{mgC} \cdot \mathrm{m}^{-2}$ at $1000 \mathrm{~m}$ for the megafauna, which would require $14 \%$ of the daily food input. Combining these megafauna data with our macrofauna data creates, for respiration only, an organic $\mathrm{C}$ deficiency of $\sim 2 \mathrm{~g} \cdot \mathrm{m}^{-2} \cdot \mathrm{y}^{-1}$. Thus an additional (horizontal) input is required at $\sim 1000 \mathrm{~m}$ water depth. At a bathyal mid-slope $(2000 \mathrm{~m})$ site in the Porcupine Seabight, Lampitt et al. (1995) found that the vertical flux was sufficient to fuel only $20 \%$ of the benthic oxygen demand. They conclude that substantial quantities of material are transported to this mid-slope region to provide the organic carbon required by the sediment. At an abyssal $(4800 \mathrm{~m})$ site in the Porcupine Abyssal Plain, they found that the organic carbon required to fuel benthic oxygen demand was similar to the estimated vertical supply. Hinga et al. (1979) also concluded from comparisons of sediment-trap fluxes with benthic oxygen consumption that the vertical flux of $P O C$ is adequate to fuel the deep $(3500 \mathrm{~m})$ benthos (comparable with OMEX-III), but that an additional input is required at shallower $(600,1300 \mathrm{~m})$ depths.

The results of our study provide evidence for seasonal and year-to-year variation in organic matter input, which is reflected in the macrofaunal community. There appears to be a real break-point at the slope break at $\sim 1500 \mathrm{~m}$, the shallower stations showing a seasonal input pattern and a macrobenthic community different from those of the deeper stations. Around $\sim 1000 \mathrm{~m}$ there seems to be an input of labile organic matter, resulting in a high macrofaunal biomass.

Acknowledgements.-We thank Adri Sandee for collecting the samples during the three cruises, and in co-operation with Joop Nieuwenhuize, for analysing the sediment composition. We are very grateful to Robin Harvey, SAMS, Oban, Scotland, for help with identification of the Echinodermata and the Mollusca. We would also like to thank the crew of the RV 'Pelagia' and RV 'Charles Darwin' and the colleagues of NIOZ, Texel, for the support received during the cruises. This study was financially supported through the OMEX programme (MAST II, Ass. contract no. 20 (Mas2-CT93-0069) and ship-time was funded by the Netherlands Geoscience Foundation GOA and NIOZ. This is publication number 2163 of the Netherlands Institute of Ecology.

\section{REFERENCES}

Antia, A, B. Von Bodungen, R. Peinert \& M. Voß, 1995. Recording the quantity and quality of organic particle flux from the epipelagic zone to the seafloor. OMEX Second Annual Report, part C: 1-9.

Billett, D.S.M., R.S. Lampitt, A.L. Rice \& R.F.C. Mantoura, 1983. Seasonal sedimentation of phytoplankton to the deep sea benthos.-Nature 302: 520-522.

Blake, J.A. \& L. Watling, 1994. Life history studies of deep-sea benthic infauna: Polychaeta, Aplacophora and Cumacea from the continental slope off Massachusetts. In: C.M. Young \& K.J. Eckelbarger. Reproduction, larval biology and recruitment of the deep-sea benthos. Columbia University Press, New York: 244-260

Flach, E. \& C. Heip, 1996. Vertical distribution of macrozoobenthos within the sediment on the continental slope of the Goban Spur area (NE Atlantic).-Mar. Ecol. Prog. Ser. 141: $55-66$.

Gage, J.D. \& P.A. Tyler, 1981. Non-viable seasonal settlement of larvae of the upper bathyal brittle star Ophiocten gracilis in the Rockall Trough Abyssal.-Mar. Biol. 64: 153-161.

1982a. Depth-related gradients in size structure and bathymetric zonation of deep-sea brittle stars.-Mar. Biol. 71: 299-308.

1982b. Growth strategies in deep-sea ophiuroids. In J.M. Lawrence. International Echinoderms Conference, 
Tampa Bay. A.A. Balkema, Rotterdam: 305-311.

_ $1982 \mathrm{c}$. Growth and reproduction of the deep-sea brittlestar Ophiomusium Iymani Wyville Thomson.-Oceanologica Acta 5: 73-83.

Gooday, A.J. \& P.J.D. Lambshead, 1989. Influence of seasonally deposited phytodetritus on benthic foraminiferal populations in the bathyal northeast Atlantic: the species response.-Mar. Ecol. Prog. Ser. 58: 53-67.

Gooday, A.J. \& C.M. Turley, 1990. Responses by benthic organisms to inputs of organic material to the ocean floor: a review.-Phil. Trans. R. Soc. Lond. A 331: 119-138.

Gooday, A.J., O. Pfannkuche \& P.J.D. Lambshead, 1996. An apparent lack of response by metazoan meiofauna to phytodetritus deposition in the bathyal north-eastern Atlantic.-J. mar. biol. Ass. U.K. 76: 297-310.

Graf, G. \& L. Thomsen, 1995. The benthic resuspension loop at the shelf break and on the continental slope. OMEX Second Annual Report, part E: 29-35.

Heip, C., E. Flach, J. Vanaverbeke \& A. Sandee, 1994. Benthic community and species diversity gradients along the OMEX transect. OMEX First Annual Report.

Heip, C., E. Flach, J. Vanaverbeke, M. Lavaleye \& A. Sandee, 1995. Benthic community and species diversity gradients along the OMEX transect. OMEX Second Annual Report, part E: 105-118.

Helder, W., 1993. Cruise report OMEX, 11-31 October 1993 with R.V. 'Pelagia': 1-28.

Hinga, K.R., J. McN. Sieburth \& G. Ross Heath, 1979. The supply and use of organic material at the deep-sea floor.-J. mar. Res. 37: 557-579.

Khripounoff, A. \& P. Crassous, 1994. Particulate material degradation in sediment traps at $2000 \mathrm{~m}$ depth on the Meriadzek Terrace (Bay of Biscay).-Deep-Sea Res. I, 41: $821-829$.

Lampitt, R.S., 1985. Evidence for the seasonal deposition of detritus to the deep-sea floor and its subsequent resuspension.-Deep-Sea Res. 32: 885-897.

Lampitt, R.S., D.S.M. Billett \& A.L. Rice, 1986. Biomass of the invertebrate megabenthos from 500 to $4100 \mathrm{~m}$ in the northeast Atlantic Ocean.-Mar. Biol. 93: 69-81.

Lampitt, R.S., R.C.T. Raine, D.S.M. Billett \& A.L. Rice, 1995. Material supply to the European continental slope: A budget based on benthic oxygen demand and organic supply.-Deep-Sea Res. I, 42: 1865-1880.

Mahaut, M.-L., M. Sibuet \& Y. Shirayama, 1995. Weight-dependent respiration rates in deep-sea organisms.-Deep-Sea Res. I, 42: 1575-1582.

Nieuwenhuize, J., Y.E.M. Maas \& J.J. Middelburg, 1994. Rapid analysis of organic carbon and nitrogen in particulate materials.-Mar. Chem. 45: 217-224.

Pearson, M. \& J.D. Gage, 1984. Diets of some deep-sea brittle stars in the Rockall Trough.-Mar. Biol. 82: 247-258.

Pfannkuche, O., 1993. Benthic response to the sedimentation of particulate organic matter at the BIOTRANS station, $47^{\circ} \mathrm{N}, 20^{\circ} \mathrm{W}$.-Deep-Sea Res. II, 40: 135-149.
Rice, A.L., D.S.M. Billett, M.H. Thurston \& R.S. Lampitt, 1991. The Institute of Oceanographic Sciences biology programme in the Porcupine Seabight: background and general introduction.-J. mar. biol. Ass. U.K. 71: 281-310.

Rice, A.L., M.H. Thurston \& B.J. Bett, 1994. The IOSDL DEEPSEAS programme: introduction and photographic evidence for the presence and absence of a seasonal input of phytodetritus at contrasting abyssal sites in the northeastern Atlantic.-Deep-Sea Res. I, 41: 1305-1320.

Rowe, G.T., 1983. Biomass and production of deep-sea macrobenthos. In: G.T. Rowe. Deep-sea biology. The Sea, Vol. 8, John Wiley \& Sons, New York: 97-121.

Scheltema, R.S., 1994. Adaptations for reproduction among deep-sea benthic molluscs: an appraisal of the existing evidence. In: C.M. Young \& K.J. Eckelbarger. Reproduction, larval biology and recruitment of the deep-sea benthos. Columbia University Press, New York: 44-75.

Thomsen, L. \& E. Flach, 1997. Mesocosm observations of fluxes of particulate matter within the benthic boundary layer. $\rightarrow$ J. Sea Res. in press

Tyler, P.A., 1986. Studies of a benthic time series: reproductive biology of benthic invertebrates in the Rockall Trough.-Proc. R. Soc. Edinb. 88B: 175-190.

Tyler, P.A. \& J.D. Gage, 1984 . The reproductive biology of echinothuriid and cidarid sea urchins from the deep sea (Rockall Trough, North-East Atlantic Ocean).-Mar. Biol. 80: 63-74.

Tyler, P.A., R. Harvey, L.A. Giles \& J.D. Gage, 1992. Reproductive strategies and diet in deep-sea nuculanid protobranchs (Bivalvia: Nuculoidea) from the Rockall Trough.-Mar. Biol. 114: 571-580

Tyler, P.A., J.D. Gage, G.J.L. Paterson \& A.L. Rice, 1993. Dietary constraints on reproductive periodicity in two sympatric deep-sea astropectinid seastars.-Mar. Biol. 115: 267-277.

Tyler, P.A., L.S. Campos-Creasey \& L.A. Giles, 1994. Environmental control of quasi-continuous and seasonal reproduction in deep-sea benthic invertebrates. In: C.M. Young \& K.J. Eckelbarger. Reproduction, larval biology and recruitment of the deep-sea benthos. Columbia University Press, New York: 158-178.

Van Weering, Tj.C.E., 1994. Cruise report OMEX, 18/5 13/6 1994, with R.R.S. 'Charles Darwin': 1-28.

Van Weering, Tj.C.E. \& H. De Stigter, 1995. Recent sediments, boundary layer dynamics and sediment accumulation at the Goban Spur margin. OMEX Second Annual Report, part E: 15-28.

Winberg, G.G., 1971. Methods for estimation of production of aquatic animals. Academic Press, London and New York.

(accepted 12 August 1996) 